\title{
Investigation and Empirical Research on the Credit Demand of High Technology SME
}

\author{
Qu Yi ${ }^{1,2}$, Zhong Shen ${ }^{3}$, Zhang Dehua ${ }^{3}$ \\ (1 School of Economics in Harbin University of Commerce, Heilongjiang, Harbin, 150028) \\ (2 Department of Finance in Harbin Vocational College of Science and Technology, Heilongjiang, Harbin, 150300) \\ (3 School of Finance in Harbin University of Commerce, Heilongjiang, Harbin, 150028)
}

\begin{abstract}
This paper builds the Tobit model to analyze the factors influencing credit demand via carrying out a survey in high technology SME of Heilongjiang technological region. The results show that the credit demand influenced by the main business, the business scale, the R\&D investment and the performance. The main business, the business scale and the R\&D investment have positive effect on the credit demand. The performance has negative effect on the credit demand. And the debt and the credit system have no effect on the credit demand.
\end{abstract}

Keywords-high technology SEM;credit demand;Tobit model

\section{COLLECTION AND COLLATION OF STATISTICAL DATA}

The survey project is supported by Heilongjiang Provincial Development and Reform Commission and Heilongjiang Provincial Academy of Social Sciences, the organization of more than ten people to use a sample survey, in March 2013 to May 2013 to carry out the questionnaire survey. This investigation uses the method of sampling and screening.

Ultimately, effective questionnaire is 417 , of which three National University Technology Parks, 347 parts, 70 parts of a provincial universities science and Technology Park, 103 software service industries, 314 other industries.

\section{THE DESCRIPTIVE ANALYSIS ON THE FACTORS}

AFFECTING THE CREDIT DEMAND OF HIGH-TECH SME

\section{A. Main business and credit demand}

Tab.I shows the two credit demand of different industries, which can be seen in the production of hightech industries higher demand for credit, accounting for $80 \%$, while the service the credit demand of high-tech industries accounted for only $35 \%$

TABLE I. THE INCIDENCE OF CREDIT DEMAND OF ENTERPRISES IN DIFFERENT INDUSTRIES IN HEILONGJIANG

\begin{tabular}{|c|c|c|}
\hline & $\begin{array}{l}\text { Productive } \\
\text { sectors }\end{array}$ & $\begin{array}{l}\text { Service } \\
\text { industry }\end{array}$ \\
\hline $\begin{array}{l}\text { The number of } \\
\text { enterprises with credit } \\
\text { demand }\end{array}$ & 251 & 36 \\
\hline $\begin{array}{l}\text { The incidence of credit } \\
\text { demand }\end{array}$ & $80 \%$ & $35 \%$ \\
\hline
\end{tabular}

\section{B. Business performance and credit demand}

Through tab., we find that the operating losses of the enterprise, the year of the profit enterprise and for three consecutive years of profitable business maintain a relatively stable state of credit demand, which is mainly high tech companies are required to maintain the core competitiveness of the enterprise itself, so the capital investment is relatively large.

\begin{tabular}{cccc}
$\begin{array}{c}\text { TABLE II. } \\
\text { OPERATING PERFORMANCE OF ENTERPRISES IN HEILONGJIANG }\end{array}$ & $\begin{array}{c}\text { THE INCIDENCE OF CREDIT DEMAND OF DIFFERENT } \\
\text { Loss- } \\
\text { making } \\
\text { enterprises } \\
\text { in those } \\
\text { years }\end{array}$ & $\begin{array}{c}\text { Profit } \\
\text { enterprise } \\
\text { in those } \\
\text { years }\end{array}$ & $\begin{array}{c}\text { Three } \\
\text { consecutive } \\
\text { years of } \\
\text { profit-making } \\
\text { enterprises }\end{array}$ \\
\hline
\end{tabular}

The number of enterprises with credit demand 25 123 139

The incidence

of credit

demand

$73 \% \quad 74 \%$

$64 \%$

C. Level of debt and credit demand

TABLE III. THE INCIDENCE OF CREDIT DEMAND OF DIFFERENT DEBT LEVELS OF ENTERPRISES IN HEILONGJIANG

$\begin{array}{cccc}\text { No } & \text { Less } & 30 \%- & 70 \% \text { or } \\ \text { debt } & \text { than } & 70 \% & \text { more }\end{array}$

$\begin{gathered}\text { The number of } \\ \text { enterprises with } \\ \text { credit demand }\end{gathered}$

Through tab.III we find that high tech SME regardless of whether the debt or not have a higher demand for credit, 
but some companies believe that with a higher debt is difficult to refinance, there are some companies that should improve the risk investment system as soon as possible to ensure that the $R$ \& $D$ results can be converted into funding as soon as possible.

\section{Business scale and credit demand}

Through tab. IV we see high tech SME are basically the case, with the scale of the expansion of the company's fixed asset investment, operating costs are gradually increasing. We need to ensure a certain operating profit to make business develop. However, 20 to 50 million-scale enterprises demand is relatively small, but it is not a reasonable explanation. In addition the service of high-tech small and medium enterprises is generally smaller with the basic distribution of 20 million or less.

TABLE IV. CREDIT DEMAND INCIDENCE OF DIFFERENT ENTERPRISES SCALE OF ENTERPRISES IN HEILONGJIANG

\begin{tabular}{cccc}
\hline & & & \\
& & & \\
Below5 & 5million- & millio & More \\
million & 20 & $\mathrm{n}-50$ & 50 \\
& million & millio & millio \\
& & $\mathrm{n}$ & $\mathrm{n}$ \\
& & & \\
\hline
\end{tabular}

\begin{tabular}{|c|c|c|c|c|}
\hline $\begin{array}{c}\text { The number } \\
\text { of enterprises } \\
\text { with credit } \\
\text { demand }\end{array}$ & 72 & 103 & 51 & 61 \\
\hline $\begin{array}{l}\text { The } \\
\text { incidence of } \\
\text { credit } \\
\text { demand }\end{array}$ & $64 \%$ & $77 \%$ & $50 \%$ & $90 \%$ \\
\hline
\end{tabular}

\section{E. $R \& D$ investment and credit demand}

Through tab. V we can see that there are credit demands of enterprises in R \& D investment accounted for $66 \%$, the other for the expansion of business scale. And service of high-tech industry in the R \& D investment less demand, mainly because of its focus on R \& D by the human capital.

\begin{tabular}{|c|c|c|}
\hline & $\begin{array}{l}\text { Productive } \\
\text { sectors }\end{array}$ & $\begin{array}{l}\text { Service } \\
\text { sectors }\end{array}$ \\
\hline $\begin{array}{l}\text { Number of R \& D enterprise } \\
\text { credit demand }\end{array}$ & 189 & 14 \\
\hline $\begin{array}{l}\mathrm{R} \& \mathrm{D} \text { investment accounted } \\
\text { for }\end{array}$ & $75 \%$ & $40 \%$ \\
\hline
\end{tabular}

\section{F. Credit system and credit demand}

No matter how the system changes in credit, business credit demand changes little, probably because of the country supporting high technology industries and making efforts to large and small and medium enterprises under investigation in the university industrial parks. The local government also has a certain degree of support, so it has little effect on changes in the credit system.

TABLE VI. THE INCIDENCE OF CREDIT DEMAND OF DIFFERENT CREDIT S YSTEM OF ENTERPRISES IN HEILONGJIANG

\begin{tabular}{ccc}
\hline & $\begin{array}{c}\text { Original } \\
\text { credit system }\end{array}$ & $\begin{array}{c}\text { loosening } \\
\text { of credit } \\
\text { system }\end{array}$ \\
\hline $\begin{array}{c}\text { The number of enterprises } \\
\text { with credit demand } \\
\text { The incidence of credit } \\
\text { demand }\end{array}$ & 287 & 303 \\
\hline
\end{tabular}

III. EMPIRICAL ANALYSIS OF CREDIT DEMAND OF HIGH TECHNOLOGY SME

\section{A. Tobit model description}

Tobit model, also known as censored normal regression model, is a model of the loss of the model from the following 0 points in which is a linear regression on latent variables, which can add errors are normally distributed and the same variance [1-5]. Thus, there are:

$$
y^{*}=\mathrm{X}^{\prime} \beta+\varepsilon
$$

Among them, the error term is:

$$
\varepsilon \square N\left[0, \sigma^{2}\right]
$$

For different observation values, it has constant value variance $\sigma^{2}$. This implies latent variable $y^{*} \square N\left[\mathrm{X}^{\prime} \beta, \sigma^{2}\right]$. Observable $y$ is in line with $L=0$. This result can be defined by the censored data, so there is:

$$
y= \begin{cases}y^{*}, & \text { 当 } \mathrm{y}^{*} \succ 0 \\ -, & \text { 当 } \mathrm{y}^{*} \leq 0\end{cases}
$$

Among them, the "-" indicates ${ }^{y}$ as the absence is observable. When $y^{*} \leq 0$, the special value of $y_{\text {is not }}$ necessarily observable.

Equations (1) - (3) define the original Tobit model by Tobin (1958) analysis. More generally, the Tobit model is based on the formula (1) and (2) about the latent variables, but it can have other mechanisms, including the loss from above, from below and above (two-part limit Tobit model), and interval censored data. These models sometimes become generalized Tobit models.

\section{B. Variable Selection}

Here, the variable interpreted is a response variable of high-tech SME, which varies with the different enterprises. Since the object of our analysis is the existence of corporate credit demand, namely the explanatory variables take only two values, binary choice for this problem, generally will be interpreted as a dummy variable defined, 
the value is 0 and 1 , which 0 represents no corporate demand for credit, 1 credit demand enterprises [6-9].

Explanatory variables, the variables that affect the demands of high tech SME should be the main features of the enterprise, including the enterprise's main business (INDU), business performance (PERF), debt level (DEBT), enterprise scale (SCAL), R \& D investment (RD), credit system (INST). To this end, we introduce these 6 factors as explanatory variables into the Tobit model.

\section{Empirical results}

Using the Tobit model in Eviews6.0, the measurement results of the questionnaire data are shown in Tab. VII.

TABLE VII. TABLE VII ESTIMATION RESULTS OF THE TOBIT MODEL

\begin{tabular}{ccccc} 
& & & & \\
& Coefficient & Std. Error & Z- & Prob. \\
& & & Statistic & \\
\hline INDU & 0.743638 & $0.675532 * *$ & 1.311569 & 0.0124 \\
& & & & \\
PERF & -0.799732 & $0.854721 *$ & -2.25188 & 0.0371 \\
& & & & \\
DEBT & -0.001376 & 0.211008 & -1.91001 & 0.2213 \\
& & & & \\
SCAL & 0.536742 & $0.437781 *$ & 1.14199 & 0.0791 \\
& & & & \\
RD & 0.852745 & $0.443711 * * *$ & 2.91007 & 0.0046 \\
& & & & \\
INST & 0.030462 & 0.005327 & 1.11547 & 0.4116 \\
\hline
\end{tabular}

Note: $* * *, * * * *$ respectively represent $1 \%, 5 \%, 10 \%$ level of statistical significant

As can be seen from table 7, the main business (INDU) and $\mathrm{R} \& \mathrm{D}$ investment (RD) are at the $5 \%$ level of statistical significant, business performance (PERF) and enterprise scale (SCAL) are at the 10\% significant level. This shows that through the Tobit analysis of the results of the questionnaire, the above four factors have a significant impact on credit demand [10].

From the perspective of significant test of regression coefficient, the main business (INDU), enterprise scale (SCAL), R \& D investment (RD) will have a positive impact on credit demand, while the operating performance (PERF) will have a negative impact on credit demand[11].

The two indicators of corporate debt (DEBT) and credit systems (INST) also, as we determine is not significant, mainly because of the high-tech SMEs in the technology park is generally able to obtain national and local government policy support, so companies will not do more consideration at these factors[12].

\section{CONCLUSIONS}

Based on survey data of 417 colleges and universities in Heilongjiang Province, this paper constructs the Tobit model, and analyzes the influence factors of credit demand of high tech SME [13]. The results of empirical studies show that the factors that affect the credit demand of the enterprise mainly include the main business, enterprise scale, R \& D investment and business performance [14]. Among them, the main business, enterprise size, R \& D investment in the enterprise credit demand has a positive effect; business performance is a negative effect on corporate credit demand. And corporate debt and credit system have no significant impact on corporate credit demand. It is worth noting that, in the results of the estimation; the main business and $\mathrm{R} \& \mathrm{D}$ investment in corporate credit are the most significant, followed by business performance and corporate scale [15]. This shows that the high tech SME are more restricted by the industry and the development of the credit capital is more to invest in the core technology of the enterprise.

\section{ACKNOWLEDGEMENT}

This project is supported by the National Social Science Fund Project "Transfer of Financial Perspective Adjustment of China's Rural Financial System"(13BJY087).

\section{REFERENCE}

[1] Liang Bing Development and financing survey report of Chinese SME [J] Financial Research, 2004 (5): 120-138

[2] Lin Yifu, Li Yongjun. Development of small and medium financial structure and SME financing [J]. Economic Research, 2001 (1): 10-18,

[3] BAAS SCHROOTEN., Relationship banking and SEMs: A theoretical analysis [J]. Discussion Paper German Institute of Economic Research, Berlin, 2005

[4] Wu Yechun, Wang Cheng. Empirical research on the growth factor model of SMEs [J]. Special Zone Economy, 2007 (6): 268269

[5] Lin Wenqiong, Zhang Wenqi, Zheng Jinghui, Xie Shuichang. The empirical study of social capital in rural small and medium enterprises in the informal credit availability [J] Technical Economic, 2009 (5): 53-58

[6] Wan Qian, Liu Li. Regional financial environment and financing behavior of SMEs [J]. Finance Forum, 2010 (10): 73-80

[7] Zhang Jiangang, Wang Shanshan, Wang Hongqi. Research on the development strategy of Science and Technology Park of universities in Heilongjiang [J].Technical Economy, 2004 (1): 1114

[8] Patton M. P, Kostov, S, McErlean, and J Moss. Assessing The Influence of Direct Payments On The Rental Value Of Agricultural Land [J]. Food Policy, 2008, Vol. 33 (5): 397-405.

[9] Kirwan, B. The Incidence of U.S. Agricultural Subsidies on Farmland Rental Rates [J]. Journal of Political Economy, 2009 (117): 138-164.

[10] Zhang Dehua, Zhou Huiqiu and Lou Sha. The problems and the countermeasures in food production in Heilongiiang [J]. Research of Agricultural Modernization. 2012(4):411-414.

[11] Lou Sha, Liu Huiping, Zhang Dehua. Comparative study on grain production and farmers' income coordination in Heilongjiang [J]. Research of Agricultural Modernization. 2013, Vol.34 (6):654658.

[12] Patton M. P, Kostov, S, McErlean, and J Moss. Assessing The Influence of Direct Payments On The Rental Value Of Agricultural Land [J]. Food Policy. 2008, Vol. 33(5): 397-405.

[13] Zhou Qiren. Property and Institutional Change [M]. Beijing University Press, 2004.

[14] Zhang Dehua. Study on influential factors and countermeasures of farmers' income in Heilongjiang $[\mathrm{M}]$. Harbin: Northeast Agricultural University, 2013.

[15] Chen Yin'e, Xing Naiqian, Shi Wenming, Impact of rura infrastructure investment on farmers' income - An empirical study based on dynamic panel data model [J] Journal of Zhongnan University of Economics and Law, 2012 (1): 97- 102 